\title{
PENINGKATAN PENDAPATAN ASLI DAERAH DALAM RANGKA OTONOMI DAERAH MELALUI POTENSI PAJAK DAN RETRIBUSI DAERAH DI KABUPATEN JAYAPURA
}

\author{
Parson Horota ${ }^{1}$ \\ jurnalmkd@gmail.com \\ Ida Ayu Purba Riani ${ }^{2}$ \\ pubariani@gmail.com \\ Robert. M. Marbun ${ }^{3}$ \\ robertmarbun@gmail.com
}

\begin{abstract}
This study aims to analyze local revenue potential of Jayapura regency sourced from local taxes and levies, and identify the obstacles faced so that the contribution has not yet been effectively implemented and also the strategies to overcome the constraints in order to increase local revenue (PAD) through the potential of local taxes and levies.

The research was using cluster sampling and simple random sampling methods. Data gathering technique in this research was interview, qusionary, and literature study. Type and a source of the data were primary and secondary data.

The result of this research showed that the regional taxes and levies collection in Jayapura regency have not yet optimal, so that the contribution to PAD are still relatively low. Whereas this region has great tax potential, especially duties on land and building transfer (BPHTB), hotel tax, restaurant tax, parking tax, and non rock and metal taxes, which were not excavated optimally. Similarly local levies which has large potential, particularly the health service levy, disturbance permit, and garbage service. Hence, immediately effective strategy implementation to improve the charges result according to available potentials, that are able to encourage significantly PAD increase in the future.
\end{abstract}

Keyword: local revenue (PAD), obstacle factors, local taxes and levies potential increasing strategies

\section{PENDAHULUAN}

Untuk mewujudkan kemampuan dan kemandirian daerah serta memperkuat struktur penerimaan daerah, maka kontibusi PAD dalam struktur APBD harus senantiasa ditingkatkan karena merupakan salah satu tolok ukur kemampuan dan cermin kemandirian daerah. Minimnya perolehan PAD masih dianggap sebagai hambatan dan ini harus segera dievaluasi secara sungguh-sungguh oleh masingmasing pemerintah daerah dalam upaya peningkatan pelayanan dan fasilitasi kepada masyarakat. Padahal, kurang efektif dan efisiennya target untuk mencapai realita pemenuhan kebutuhan masyarakat merupakan salah satu hal yang menjadi pangkal permasalahan kurang tercapainya pendapatan daerah selama ini.

\footnotetext{
${ }^{1}$ Alumni Mahasiswa Magister Keuangan Daerah Universitas Cenderawasih

${ }^{2}$ Staf Dosen Jurusan Ilmu Ekonomi Fakultas Ekonomi dan Bisnis Universitas Cenderawasih

${ }^{3}$ Staf Dosen Jurusan IImu Ekonomi Fakultas Ekonomi dan Bisnis Universitas Cenderawasih
} 
Sampai saat ini, masih belum tergalinya potensi pendapatan daerah pada umumnya disebabkan oleh faktor kurangnya kepekaan Pemda dalam menemukan keunggulan budaya dan potensi pendapatan asli daerah (PAD), kepatuhan dan kesadaran wajib pajak/retribusi yang relatif rendah, lemahnya sistem hukum dan administrasi pendapatan daerah, kelemahan aparatur, kekhawatiran birokrasi akan kegagalan dalam menjalankan programnya, ketidakoptimisan akan hasil yang mungkin dicapai.

Apabila PAD dapat dioptimalkan dan dikelola secara profesional dengan menemukan keunggulan budaya dan potensi asli daerah serta kemauan yang kuat dari seluruh stakeholder, maka akan dapat menumbuhkan daya saing daerah yang kompetitif serta meningkatkan kesejahteraan masyarakat melalui program yang prorakyat.

Sumber penerimaan daerah mengacu kepada Undang-Undang tentang perimbangan keuangan antara pusat dan daerah yang besarnya disesuaikan dan diselaraskan dengan pembagian kewenangan antara pemerintah pusat dan pemerintah daerah. Dalam hal ini, pemerintah daerah diberi hak untuk mendapatkan sumber keuangan berupa kepastian tersedianya pendanaan dari pemerintah sesuai urusan pemerintahan yang diserahkan yakni kewenangan memungut sekaligus mendayagunakan pajak dan retribusi daerah, hak untuk mendapatkan bagi hasil dari sumbersumber daya nasional yang berada di daerah dan dana perimbangan lainnya serta untuk mengelola kekayaan daerah dan mendapatkan sumbersumber pembiayaan dengan prinsip dasarnya uang mengikuti fungsi (Money Follow Function) (Yuwono,2008).

Penerimaan daerah yang bersumber Pendapatan Asli Daerah (PAD) diwujudkan di masing-masing daerah melalui kewenangan untuk memungut pajak dan retribusi daerah yang telah diatur dalam peraturan perundang-undangan, antara lain Undang-Undang Nomor 34 Tahun 2000 yang telah diperbaharui dengan lahirnya Undang-Undang Nomor 28 tahun 2009 tentang Pajak Daerah dan Retribusi Daerah. Dimana Undang-Undang Nomor 34 tahun 2000 telah memberikan kewenangan kepada pemerintah kabupaten/kota untuk memungut 7 jenis pajak daerah dan 25 jenis retribusi daerah dan setiap daerah masih diberikan kewenangan untuk memungut retribusi lainnya sesuai dengan potensi yang dimiliki masing-masing (open list) sepanjang tidak bertentang dengan peraturan perundangundangan di atas. Demikian pula Undang-Undang Nomor 28 tahun 2009 telah memberikan kewenangan kepada pemerintah kabupaten/kota, termasuk pemerintah Kabupaten Jayapura, untuk memungut 11 jenis pajak daerah dan 30 jenis retribusi 
daerah (sifatnya close list). Namun demikian, dengan mempertimbangkan potensi dan kemajuan pembangunan daerah, maka Pemkab Jayapura saat ini hanya memungut 7 jenis pajak daerah.

Kemudian dari 30 jenis retribusi daerah yang dicantumkan dalam UndangUndang Nomor 28 Tahun 2009, hanya ada 13 jenis retribusi yang telah dipungut oleh pemkab Jayapura dari masyarakat, sehingga masih terdapat 17 jenis retribusi yang belum sepenuhnya dikelola. Semestinya dengan mempertimbangkan faktor perkembangan aktivitas pembangunan ekonomi Kabupaten Jayapura yang sangat pesat, sepatutnya Pemkab Jayapura memungut pula 17 jenis retribusi tersebut.

Akibatnya, meskipun pemkab Jayapura telah diberikan kewenangan yang lebih besar dan luas untuk memungut pajak dan retribusi daerah sesuai dengan potensi daerah yang dimiliki, namun terlihat bahwa kontribusi Pendapatan Asli Daerah (PAD) dalam total pendapatan daerah ini masih relatif kecil, yakni berkisar antara $3,5 \%-6,0 \%$, sehingga belum dapat dikategorikan sebagai daerah yang mandiri dalam memenuhi kebutuhan anggaran pembiayaan pembangunan daerahnya.

Di era otonomi daerah saat ini, setiap pemerintah daerah kabupaten/kota, termasuk pemerintah Kabupaten Jayapura, diberikan kewenangan yang lebih besar untuk mengatur dan mengurus rumah tangganya sendiri, diantaranya kewenangan untuk mengatur keuangannya dalam rangka pelaksanaan tugas pokok dan fungsi pemerintahan, aktivitas pembangunan dan pelayanan kepada masyarakat. Tujuannya antara lain adalah untuk lebih mendekatkan pelayanan pemerintah kepada masyarakat, memudahkan masyarakat untuk memantau dan mengontrol penggunaan dana yang bersumber dari Anggaran Pendapatan dan Belanja Daerah (APBD) serta untuk mengeliminir ketimpangan antar daerah dan mendorong timbulnya inovasi di masing-masing daerah.

Sejalan dengan kewenangan tersebut, maka Pemda diharapkan lebih mampu menggali sumber-sumber keuangan daerahnya masing-masing, utamanya untuk memenuhi pembiyaan pemerintahan dan pembangunan di daerahnya melalui Pendapatan Asli Daerah (PAD). Oleh karena itu, tuntutan optimalisasi penggalian potensi PAD di setiap daerah, termasuk di Kabupaten Jayapura, semakin besar seiring dengan semakin banyaknya kewenangan pemerintahan yang dilimpahkan oleh pemerintah pusat kepada pemerintah daerah.

Dalam rangka mewujudkan tujuan ini, maka pemkab Jayapura perlu untuk segera melakukan berbagai upaya dalam rangka mendorong peningkatan PAD dari tahun ke tahun. Salah satu bentuk upaya yang efektif dan urgen untuk diterapkan 
saat ini adalah menggali dan mengelola potensi PAD Kabupaten Jayapura secara optimal, sehingga kontribusi PAD terhadap APBD dapat dioptimalkan di tahun-tahun mendatang. Terkait dengan hal tersebut, maka penulis melihat urgensi meneliti upaya pemkab Jayapura untuk meningkatkan Pendapatan Asli Daerah (PAD) Kabupaten Jayapura melalui optimalisasi pajak daerah dan retribusi daerah. Berdasarkan perspektif pentingnya penelitian ini, maka penulis memilih topik yang lebih spesifik, yakni: "Peningkatan Pendapatan Asli Daerah Dalam Rangka Otonomi Daerah Melalui Optimalisasi Pajak Daerah dan Retribusi Daerah di Kabupaten Jayapura".Berdasarkan uraian pada latar belakang, maka selanjutnya dapat dirumuskan beberapa masalah pokok yang dikaji dalam penelitian ini, yakni: (1) Bagaimana potensi PAD yang bersumber dari Pajak Daerah dan Retribusi Daerah di Kabupaten Jayapura; (2) Faktor-faktor apa yang menjadi kendala, sehingga Potensi Pajak Daerah dan Retribusi Daerah di Kabupaten Jayapura belum optimal; (3) Strategi apa yang efektif diterapkan untuk meningkatkan potensi Pajak dan Retribusi Daerah guna mendorong peningkatan kontribusi PAD terhadap total pendapatan daerah di Kabupaten Jayapura di masa datang. Sedangkan tujuan penelitian adalah (1) Mengalisis besarnya potensi PAD yang bersumber dari Pajak Daerah dan Retribusi Daerah di Kabupaten Jayapura; (2) Mengetahui faktor-faktor kendala, sehingga Pengelolaan Pajak Daerah dan Retribusi Daerah di Kabupaten Jayapura belum optimal; (3) Menyusun strategi yang efektif diterapkan untuk mengoptimalkan pengelolaan Pajak Daerah dan Retribusi Daerah guna mendorong peningkatan kontribusi PAD terhadap total pendapatan daerah di Kabupaten Jayapura di masa datang.

Hasil penelitian ini diharapkan dapat digunakan sebagai bahan masukan atau referensi bagi pemkab Jayapura dalam memformulasi perencanaan dan implementasi kebijakan dalam bentuk penetapan strategi atau pendekatan yang efisien dan efektif diterapkan dalam rangka mendorong peningkatan kontribusi Pendapatan Asli Daerah (PAD) dalam Total Pendapatan Daerah Kabupaten Jayapura melalui upaya optimalisasi pajak daerah dan retribusi daerah di masa datang sebagai salah satu wujud upaya serius pemerintah Kabupaten Jayapura untuk mencapai kemadirian keuangan daerah ini dalam menjalankan fungsi dan tugas pemerintahan, pembangunan daerah dan pelayanan kepada masyarakat.

\section{Kebijakan Otonomi Daerah}

Kebijakan otonomi daerah merupakan kebijakan yang menggeser dominasi penyelenggaraan pemerintahan dari pusat ke daerah. Pergeseran ini memberikan 
peluang dan sekaligus tantangan bagi daerah untuk meningkatkan kualitas penyelenggaraan kepemerintahaanya serta meningkatkan akselerasi pembangunan didaerahnya. Tujuan umum dari kebijakan otonomi daerah/desentralisasi sebagaimana tersirat dalam Undang-Undang No.32 Tahun 2004 adalah :

- Memberi peluang dan kesempatan bagi terwujudnya pemerintah yang baik dan bersih (clean and good governance) di daerah dalam pelayanan publik, yang berarti pelaksanaan tugas pemerintah daerah harus didasarkan atas prinsip : efektif, efisien, terbuka, dan akuntabel.

- Meningkatkan kesejahteraan rakyat dengan selalu memperhatikan kepentingan dan aspirasi yang tumbuh dalam masyarakat;

- Menjamin keserasian hubungan antara daerah satu dengan daerah lainnya, artinya mampu membangun kerjasama antar daerah dengan daerah lainnya untuk meningkatkan kesejahteraan bersama dan mencegah ketimpangan antar daerah;

- Menjamin hubungan yang serasi antara daerah dengan pemerintah, artinya harus mampu memelihara dan menjaga keutuhan wilayah Negara dan tetap tegaknya Negara Kesatuan Republik Indonesia dalam rangka mewujudkan tujuan Negara.

- Meningkatkan daya saing daerah untuk mendukung ekonomi nasional.

Menurut Saragih (2003) bahwa salah satu tujuan dari kebijakan otonomi daerah/desentralisasi adalah memberdayakan masyarakat lokal (setempat) sehingga memungkinkan masyarakat lokal untuk dapat menikmati kualitas kehidupan yang lebih baik, maju, tenteram, dan sekaligus memperluas pilihanpilihan (choices) yang dapat dilakukan masyarakat.

Salah satu aspek yang mendukung berhasilnya kebijakan otonomi daerah (desentralisasi) adalah aspek ekonomi, yaitu perlunya dukungan sumberdaya (resources) yang memadai dan cukup. Untuk itu, dikeluarkanlah kebijakan desentralisasi fiskal yang bertujuan untuk meningkatkan "efektifitas" penyelenggaraan pemerintahan dan pelayanan publik, serta sebagai langkah untuk mendukung dan meningkatkan kemampuan keuangan pemerintah daerah dalam melaksanakan otonomi.

Desentralisasi fiskal merupakan suatu proses distribusi anggaran dari tingkat pemerintahan yang lebih tinggi kepada pemerintahan yang lebih rendah untuk mendukung fungsi atau tugas pemerintahan dan pelayanan publik sesuai dengan banyaknya kewenangan bidang pemerintahan yang dilimpahkan tergantung kepada 
daerah yang bersangkutan sesuai dengan kreativitas, kemampuan organisasi pemerintahan daerah serta kondisi setiap daerah.

Dalam rangka pelaksanaan otonomi, tidak dapat dipungkiri bahwa dalam menjalankan implementasi otonomi sepenuhnya sangat diperlukan dana yang memadai. Oleh karena itu, melalui implementasi Undang-Undang Nomor 33 tahun 2004, diharapkan kemampuan daerah untuk memperoleh dana atau anggaran belanjanya dapat ditingkatkan seiring dengan peningkatan kebutuhan daerah. Sebagai daerah otonom, setiap daerah kabupaten/kota dituntut untuk dapat mengembangkan dan mengoptimalkan semua potensinya yang dapat digali dari wilayah daerah bersangkutan yang terdiri dari hasil pajak daerah, hasil retribusi daerah, pengelolaan kekayaan yang dipisahkan, dan lain-lain pendapatan asli daerah yang sah yang menjadi sumber PAD dalam kaitannya dengan pemenuhan kewajiban pemerintah untuk meningkatkan tingkat kesejahteraan rakyatnya serta menjaga dan memelihara ketentraman dan ketertiban masyarakat. Ciri utama suatu daerah mampu melaksanakan otonomi daerah adalah:

(1) Kemampuan keuangan daerah, yang berarti daerah tersebut memiliki kemampuan dan kewenangan untuk menggali sumber-sumber keuangannya, mengelolah dan menggunakan keuangannya sendiri untuk membiayai penyelenggaraan pemerintahan di daerahnya masing-masing; dan

(2) Ketergantungan kepada sumber keuangan terbesar yang didukung oleh kebijakan perimbangan keuangan pemerintah pusat dan daerah sebagai prasyarat dalam sistem pemerintahan negara. Dalam artian bahwa keberhasilan pengembangan otonomi daerah bisa dilihat dari derajat otonomi fiscal daerah, yakni perbandingan antara PAD dengan total penerimaan daerah dalam APBD yang semakin meningkat dari tahun ke tahun.

Penerimaan Kabupaten/Kota yang tercermin dalam APBD berasal dari PAD, yaitu pajak daerah, retribusi daerah, bagian laba BUMD, penerimaan dari dinasdinas dan penerimaan lain-lain, serta penerimaan dari bagi hasil bukan pajak, sumbangan dan bantuan, baik pemerintah pusat maupun dari pemerintah Provinsi sebagai atasannya serta penerimaan pembangunan berupa pinjaman daerah. Oleh karena itu, disamping proyek pemerintah pusat dan proyek pemerintah Provinsi yang berada di Kabupaten/Kota, terdapat pula proyek Kabupaten/Kota yang tercermin dalam APBD Kabupaten/Kota bersangkutan, dimana didalamnya terdapat komponen PAD yang bebas dipergunakan oleh Kabupaten/Kota tersebut sesuai 
dengan skala prioritasnya. Bahkan peranan PAD Kabupaten/Kota dalam pembangunan daerah sangat penting, karena kadang-kadang diperlukan sebagai dana pendamping untuk proyek pusat. Hal ini sejalan dengan pendapat Mardiasmo (2004) bahwa di sisi penerimaan, kemampuan pemerintah daerah dalam meningkatkan penerimaan daerahnya secara berkesinambungan masih lemah.Bahkan masalah yang sering muncul adalah rendahnya kemampuan pemerintah daerah untuk meghasilkan prediksi (perkiraan) penerimaan daerah yang sangat akurat, sehingga belum dapat dipungut secara optimal.

\section{Pendapatan Daerah}

Seluruh jenis pendapatan yang diterima oleh pemerintah daerah serta seluruh jenis pembiayaan (pengeluaran) daerah yang dilakukan dalam rangka menjalankan tugas pemerintahan dan program pembangunan, secara jelas tercantum dalam anggaran pendapatan dan belanja daerah (APBD) yang disusun setiap tahun oleh masing-masing daerah.

Secara garis besar, sumber pembiayaan (pendapatan) ini dapat diklasifikasikan ke dalam dua kategori sumber pembiayaan, yakni: (1) pendapatan yang diperoleh pemerintah daerah dari sumber-sumber di luar pemerintah daerah (external source). Pendapatan ini merupakan pendapatan yang diperoleh dari sumber yang berasal dari pihak luar dan tidak secara langsung ditangani sumber sendiri oleh pemerintah daerah. Pihak luar yang dimaksud adalah pihak-pihak yang berada di luar pemerintah daerah yang bersangkutan (selain pemerintah daerah beserta perangkatnya) dan bukan merupakan penduduk daerah yang bersangkutan, seperti pemerintah pusat, tingkatan pemerintahan yang ada di atas pemerintahan daerah yang bersangkutan, negara asing, pihak swasta, dan pihak ketiga; dan (2) pendapatan yang diperoleh pemerintah daerah dari sumber-sumber yang dikelola oleh pemerintah daerah itu sendiri (local source). Kategori pendapatan yang kedua ini merupakan pendapatan yang digali dan ditangani sendiri oleh pemerintah daerah dari sumber-sumber pendapatan yang terdapat dalam wilayah yurisdiksinya. Pendapatan yang termasuk ke dalam kategori pendapatan ini adalah pajak daerah (local tax, sub national tax), retribusi daerah (local retribution, fees, local licence) dan hasil-hasil badan usaha (local owned enterprises) yang dimiliki oleh daerah. Ketiga jenis pendapatan ini merupakan pendapatan yang digali dan ditangani sendiri oleh pemerintah daerah dari sumber-sumber pendapatan yang terdapat dalam wilayah yurisdiksinya. 
Berkaitan dengan hal ini, maka dalam UU No. 33 Tahun 2004 telah ditegaskan bahwa Pendapatan daerah adalah semua penerimaan uang melalui rekening kas umum daerah yang menambah ekuitas dana lancar yang merupakan hak pemerintah daerah dalam 1 (satu) tahun anggaran yang tidak perlu dibayar kembali oleh daerah. Sehubungan dengan hal tersebut, pendapatan daerah yang dianggarkan dalam APBD merupakan perkiraan yang terukur secara rasional yang dapat dicapai untuk setiap sumber pendapatan.

Pendapatan Daerah merupakan hak Pemerintah daerah yang diakui sebagai penambah nilai kekayaan bersih dalam periode yang bersangkutan.Semua barang dan jasa sebagai hasil dari kegiatan-kegiatan ekonomi yang beroperasi di wilayah domestik, tanpa memerhatikan apakah faktor produksinya berasal dari atau dimiliki oleh penduduk daerah tersebut, merupakan "Produk Domestik Regional Bruto" (PDRB) daerah bersangkutan.Pendapatan yang timbul oleh karena adanya kegiatan produksi tersebut merupakan "Pendapatan Regional". Selanjutnya, di dalam UU No 33 Tahun 2004 telah ditegaskan pula bahwa Sumber Pendapatan Daerah terdiri dari; a) Pendapatan Asli Daerah, b) Dana Perimbangan, c) Lain-lain penerimaan yang sah.

\section{Pendapatan Asli Daerah}

Menurut UU No 33 tahun 2004, Pendapatan Asli Daerah (PAD) adalah pendapatan yang diperoleh daerah yang dipungut berdasarkan peraturan daerah sesuai dengan peraturan perundang-undangan, terdiri dari : (a). Pajak daerah, (b) Retribusi daerah, (c) Hasil pengelolaan kekayaan daerah yang dipisahkan, (d) Lainlain pendapatan asli daerah yang sah

Insukindro, dkk.(1994) mengemukakan bahwa Pendapatan Asli Daerah (PAD) dapat dipandang sebagai salah satu indikator atau kriteria untuk mengukur tingkat ketergantungan suatu daerah kepada pemerintah daerah. Pada prinsipnya, semakin besar sumbangan PAD kepada APBD akan menunjukkan semakin kecilnya tingkat ketergantungan pemerintah daerah kepada pemerintah pusat. Dalam rangka implementasi Undang-undang Nomor 32 tahun 2004 dan UndangUndang Nomor 33 tahun 2004, maka salah satu faktor yang harus dipersiapkan oleh pemerintah daerah adalah kemampuan keuangan daerah, sedangkan indikator yang dipergunakan untuk mengukur kemampuan keuangan daerah tersebut ialah rasio PAD dibandingkan dengan total penerimaan APBD (Kuncoro, 2005).

Dalam perkembangan selama ini terlihat bahwa diantara semua komponen Pendapatan Asli Daerah (PAD), maka pajak daerah dan retribusi daerah merupakan 
penyumbang terbesar, sehingga muncul anggapan bahwasanya Pendapatan Asli Daerah (PAD) identik dengan pajak daerah dan retribusi daerah. Oleh karena itu, dapat dilihat bahwa pada umumnya pemerintah daerah lebih cenderung untuk menggenjot secara optimal sumber-sumber PAD daerahnya yang diperoleh dari sumber pajak daerah dan retribusi daerah dibandingkan dengan sumber-sumber PAD lainnya, termasuk laba badan usaha milik daerah, meskipun sumber-sumber lainnya tersebut memiliki potensi yang sangat besar untuk dikembangkan di daerah bersangkutan.

\section{a. Pajak Daerah}

Di dalam UU No 28 tahun 2009 tentang Pajak Daerah dan Retribusi Daerah dinyatakan bahwa Pajak Daerah, yang selanjutnya disebut Pajak, adalah kontribusi wajib kepada daerah yang terutang oleh orang pribadi atau badan yang bersifat memaksa berdasarkan Undang-Undang, dengan tidak mendapatkan imbalan secara langsung dan digunakan untuk keperluan daerah bagi sebesar-besarnya kemakmuran rakyat. Selanjutnya, di dalam UU nomor 28 tahun 2009 ditegaskan bahwa pajak kabupaten/kota dibagi menjadi beberapa jenis, yakni:

- Pajak Hotel,

- Pajak Restoran,

- Pajak Hiburan,

- Pajak Reklame,

- Pajak Penerangan Jalan,

- Pajak Mineral bukan Logam dan Batuan,

- Pajak Parkir,

- Pajak Air Tanah,

- Pajak Sarang Burung Walet,

- Pajak Bumi dan Bangunan Perdesaan dan Perkotaan, dan

- Pajak Bea Perolehan Hak atas Tanah dan Bangunan.

\section{b. Retribusi Daerah}

Menurut UU Nomor 28 Tahun 2009 secara keseluruhan terdapat 30 jenis retribusi yang dapat dipungut oleh daerah yang dikelompokkan ke dalam 3 golongan retribusi, yaitu retribusi jasa umum, retribusi jasa usaha, dan retribusi perizinan tertentu.

- Retribusi Jasa Umum yaitu pelayanan yang disediakan atau diberikan pemerintah daerah untuk tujuan kepentingan dan kemanfaatan umum serta 
dapat dinikmati oleh orang pribadi atau badan. Jenis retribusi umum adalah; (a) Retribusi layanan kesehatan; (b) Retribusi pelayanan persampahan/kebersihan; (c). Retribusi penggantian biaya cetak KTP dan Akte catatan sipil; (d) Retribusi Pelayanan Pemakaman dan pengabuan mayat; (e) Retribusi pelayanan parkir tepi jalan umum; (f) Retribusi pelayanan pasar; (g) Retribusi pengujian kenderaan bermotor; (h) Retribusi pemeriksaan alat pemadam kebakaran; (i) Retribusi penggantian biaya cetak peta; (j) Retribusi penyediaan/penyedotan kakus; (k). Retribusi pengelolaan limbah cair; (I) Retribusi pelayanan tera/tera ulang; (m) Retribusi pelayanan pendidikan; dan (n) Retribusi pengendalian Menara telekomunikasi.

- Retribusi Jasa Usaha adalah pungutan daerah sebagai pembayaran atas jasa usaha yang khusus disediakan dan/atau diberikan oleh pemerintah daerah untuk kepentingan orang pribadi atau badan. Jenis retribusi jasa usaha yakni: (a) Retribusi pemakaian kekayaan daerah; (b) Retribusi pasar grosir/pertokoan; (c) Retribusi tempat pelelangan; (d) Retribusi Terminal; (e) Retribusi tempat khusus parkir; (f) Retribusi tempat penginapanan/pesanggeraan/ villa; (g). Retribusi rumah potong hewan; (h). Retribusi pelayanan kepelabuhan; (i). Retribusi tempat rekreasi dan oleh raga; (j). Retribusi penyeberangan air; dan (k). Retribusi Penjualan produksi usaha daerah.

- Retribusi Perizinan Tertentu adalah pungutan daerah sebagai pembayarann atas pemberian izin tertentu yang khusus diberikan oleh pemerintah daerah untuk kepentingan orang pribadi atau badan. Jenis retribusi perizinan tertentu yakni; (a) Retribusi izin mendirikan bangunan; (b). Retribusi tempat penjualan minuman beralkohol; (c). Retribusi izin gangguan; (d) Retribusi Izin trayek; (e). Retribusi izin usaha perikanan.

Pungutan pajak dan retribusi daerah yang berlebihan dalam jangka pendek dapat meningkatkan pendapatan asli daerah, namun dalam jangka panjang dapat menurunkan kegiatan perekonomian, yang pada akhirnya akan menyebabkan menurunnya pendapatan asli daerah (Brahmantio ,2002). Hal ini sesuai dengan pendapat Mardiasmo 2002 yang menyatakan ; Untuk kepentingan jangka pendek pungutan yang bersifat retribusi lebih relevan dibanding pajak. Alasan yang mendasari, pungutan ini secara langsung berhubungan dengan masyarakat.

\section{c. Hasil Pengelolaan Kekayaan Daerah Yang Dipisahkan.}


Undang-Undang Nomor 33 tahun 2004 mengklasifikasikan jenis hasil pengelolaan kekayaan daerah yang dipisahkan, dirinci menurut objek pendapatan yang mencakup bagian laba atas penyertaan modal pada perusahaan milik daerah/BUMD, bagian laba atas penyertaan modal pada perusahaan milik negara/BUMN dan bagian laba atas penyertaan modal pada perusahaan milik swasta atau kelompok masyarakat. Halim (2004) menyebutkan bahwa jenis pendapatan ini meliputi objek pendapatan berikut:
a). Bagian laba perusahaan milik daerah
b). Bagian laba lembaga keuangan bank.
c). Bagian laba lembaga keuangan non bank.
d). Bagian laba atas penyertaan modal/investasi

\section{d. Lain-lain Pendapatan Asli Daerah Yang Sah}

Menurut UU No. 33 tahun 2004 menjelaskan tentang Pendapatan asli Daerah yang sah, disediakan untuk menganggarkan penerimaan daerah yang tidak termasuk dalam jenis pajak daerah, dan hasil pengelolaan kekayaan daerah yang dipisahkan. Halim (2004) menyebutkan jenis pendapatan ini meliputi objek pendapatan berikut;

a) Hasil penjualan kekayaan daerah yang tidak dipisahkan

b) Penerimaan Jasa Giro

c) Pendapatan Bunga

d) Denda keterlambatan pelaksanaan pekerjaan

e) Penerimaan ganti rugi atas kerugian/kehilangan kekayaan daerah.

Halim (2004) membedakan 2 (dua) faktor yang mempengaruhi Pendapatan Asli Daerah suatu daerah, yaitu Faktor Eksternal dan Faktor Internal. Faktor eksternal terdiri dari investasi, inflasi, PDRB dan jumlah penduduk, sedangkan faktor Internal terdiri dari sarana dan prasarana, insentif, penerimaan subsidi, penerimaan pembangunan, sumberdaya manusia, peraturan daerah, sistem dan pelaporan.

\section{Upaya Mendorong Peningkatan PAD Kabupaten/Kota}

Di Indonesia saat ini, penarikan sumberdaya ekonomi melalui pajak daerah dan retribusi daerah di setiap daerah dilakukan dengan berdasarkan pada aturan hukum yang jelas, yaitu dengan Peraturan Daerah dan Keputusan Bupati/Walikota, sehingga dapat diterapkan untuk memungut pajak dan retribusi daerah sebagai salah satu sumber penerimaan daerah. Hal ini menunjukkan adanya persamaa 
antara pajak dan retribusi, yaitu pungutan oleh pemerintah daerah kepada masyarakat yang didasarkan pada aturan hukum yang jelas dan kuat.

Penyelenggaraan otonomi daerah berdasarkan UU No. 22 Th. 1999 tentang Pemerintahan Daerah sebagai pengganti UU No. 5 Th. 1974 tentang Pokok-Pokok Pemerintahan di Daerah, telah membawa perubahan dalam penyelenggaraan tugas-tugas pemerintahan daerah provinsi/kota/kabupaten. Otonomi daerah, yang sedang dilaksanakan dewasa ini, sebagai salah satu bentuk reformasi penyelenggaraan pemerintah daerah provinsi/kota/kabupaten, dilakukan oleh pemerintah pusat sebagai jawaban terhadap tuntutan masyarakat.Reformasi ini pada hakekatnya bertujuan untuk memberdayakan pemerintah daerah provinsi/kota/kabupaten dalam mengurus dan menyelenggarakan urusan-urusan rumahtangganya sendiri dalam bingkai Negara Kesatuan Republik Indonesia. Dalam mengurus dan menyelenggarakan urusan rumahtangga daerah provinsi/kota/kabupaten yang meliputi tugas pemerintahan umum, pembangunan dan pembinaan kemasyarakatan pemerintah daerah provinsi/kabupaten/kota, menurut UU No. 33 Tahun 2004 pada Pasal 79 memiliki sumber-sumber pembiayaan yang terdiri dari:

a. Pendapatan Asli Daerah (PAD):

1) Hasil Pajak Daerah

2) Hasil Retribusi daerah

3) Hasil Perusahaan Milik Daerah, hasil pengelolaan daerah yang dipisahkan

4) Lain-lain PAD yang sah.

b. Dana Perimbangan

c. Pinjaman Daerah

d. Lain-lain Pendapatan Daerah sah.

\section{Penilaian Kinerja Sektor Publik}

James B Whittaker dalam Indra Bastian (2001) menyatakan pengukuran/ penilaian kinerja adalah suatu alat manajemen untuk meningkatkan kualitas pengambilan keputusan dan akuntabilitas. Kinerja sektor publik bersifat multidimensional, sehingga tidak ada indikator tunggal yang dapat digunakan untuk menunjukkan kinerja secara komperhensif. Pengukuran kinerja sektor publik dilakukan untuk memenuhi tiga maksud antara lain :

a. Untuk membantu memperbaiki kinerja pemerintah, sehingga akan meningkatkan efisiensi dan efektivitas organisasi sektor publik dalam pemberian pelayanan publik. 
b. Untuk pengalokasian sumber daya dan pembuatan keputusan.

c. Untuk mewujudkan pertanggung jawaban publik dan memperbaiki komunikasi kelembagaan.

Pengukuran kinerja dalam sektor publik sangat penting dilakukan untuk menilai akuntabilitas organisasi dan manajemen dalam menghasilkan pelayanan publik yang lebih baik. Akuntabilitas bukan sekedar kemampuan menunjukkan bahwa uang publik di belanjakan secara ekonomis, efektif dan efisien. Mardiasmo (2009) menjelaskan sistem pengukuran sektor publik adalah suatu sistem yang bertujuan untuk membantu manajer publik menilai pencapaian suatu strategi melalui alat ukur finansial dan non-finansial. Tujuan sistem penilaian kinerja adalah:

a. Untuk mengkomunikasikan strategi secara lebih baik;

b. Untuk mengukur kinerja finansial dan non-finansial secara berimbang;

c. Untuk mengakomodasikan pemahaman kepentingan manajer level menengah dan bawah serta memotivasi untuk mencapai goal congruence;

d. Sebagai alat untuk mencapai kepuasan berdasarkan pendekatan individual dan kemampuan kolektif yang rasional.

Selanjutnya dapat diuraikan mengenai manfaat pengukuran kinerja, antara lain :

a. Memberikan pemahaman mengenai ukuran yang digunakan untuk menilai kinerja manajemen.

b. Memberikan arah untuk mencapai target kinerja yang telah ditetapkan.

c. Untuk memonitor dan mengevaluasi pencapaian kinerja dan membandingkannya dengan tingkat kinerja serta melakukan tindakan korektif untuk memperbaiki kinerja.

d. Sebagai dasar untuk memberikan penghargaan dan hukuman (reward and punishment) secara objektif atas pencapaian prestasi yang diukur sesuai dengan sistem pengukuran kinerja yang telah disepakati.

e. Sebagai alat komunikasi antara bawahan dan pimpinan dalam rangka memperbaiki kinerja organisasi.

f. Membantu mengidentifikasi apakah kepuasan pelanggan sudah terpenuhi.

g. Membantu memahami proses kegiatan instansi pemerintah

h. Memastikan bahwa pengambilan keputusan dilakukan secara objektif. 


\section{Penelitian Terdahulu}

Berkaitan dengan rencana pelaksanaan penelitian tentang peningkatan Pendapatan Asli Daerah (PAD) dalam rangka otonomi daerah di Kabupaten Jayapura, maka terdapat beberapa kegiatan penelitian terdahulu yang relevan untuk diuraikan pada bagian ini. Hasil-hasil penelitian yang relevan tersebut, diantaranya yang dapat dikemukakan adalah hasil penelitian Subhan Purwadinata pada tahun 2010 tentang Analisis Potensi Pendapatan Asli Daerah Dan Strategi Peningkatan Kemampuan Keuangan Daerah (Studi Di Kabupaten Sumbawa). Masalah yang dikaji dalam penelitian ini adalah: (1) bagaimana penggalian potensi pendapatan daerah yang ditinjau dari Pendapatan Asli Daerah (PAD) dan komponen pendukungnya, termasuk administrasi pajak daerah, tingkat kemampuan keuangan daerah; dan (2) sejauhmana peran dan strategi pemerintah daerah meningkatkan kemampuan keuangan daerah. Hasil penelitian ini menunjukkan bahwa: (1) Potensi pendapatan Kabupaten Sumbawa didominasi dari sektor retribusi daerah sedangkan pajak daerah mengikuti tetapi keseluruhan pendapatan masih banyak dipenuhi oleh dana perimbangan dari pusat dan kontribusi PAD belum mampu membentuk kemandirian daerah. (2) Penataan administrasi pajak daerah terkendala oleh belum optimalnya pelaksanaan Sosialisasi, Mendata, Menagih tiap hari dalam kegiatan pemungutan pajak daerah.(3) Kemampuan keuangan dari potensi PAD sangat rendah dan membutuhkan pemanfaatan optimal potensi yang dimiliki daerah. (4) Kontribusi komponen PAD yang mengalami penurunan drastis yakni dari sektor pajak, dan kontribusinya jauh lebih rendah dari kontribusi retribusi daerah. (5) Pemerintah daerah dalam kebijakannya memperioritaskan penerimaan daerah dari sektor pajak daerah.

Kegiatan penelitiaan lainnya yang relevan telah dilaksanakan pula oleh Mohammad Riduansyah pada tahun 2003 dengan topik Kontribusi Pajak Daerah Dan Retribusi Daerah Terhadap Pendapatan Asli Daerah (PAD) Dan Anggaran Pendapatan Dan Belanja Daerah (APBD) Guna Mendukung Pelaksanaan Otonomi Daerah (Studi Kasus Pemerintah Daerah Kota Bogor). Masalah yang dikaji dalam penelitian ini adalah sejauhmana kontribusi penerimaan pajak daerah dan retribusi daerah terhadap perolehan pendapatan asli daerah, khususnya pada Pemerintah Daerah Kota Bogor sebagai studi kasus. Hasil penelitian ini menunjukkan bahwa Kontribusi penerimaan pajak daerah dan retribusi daerah terhadap perolehan PAD Pemerintah Kota Bogor dalam kurun waktu Tahun Anggaran (TA) 1993/1994 2000 cukup signifikan dengan rata-rata kontribusi sebesar 27,78\% per tahun. Kontribusi penerimaan pajak daerah dan retribusi daerah terhadap total perolehan 
penerimaan Pemerintah Daerah Kota Bogor tercermin dalam APBD-nya, dikaitkan dengan kemampuannya untuk melaksanakan otonomi daerah terlihat cukup baik. Komponen pajak daerah dalam kurun waktu TA 1993/1994 - 2000 rata-rata pertahunnya memberikan kontribusi sebesar $7,81 \%$ per tahun dengan rata-rata pertumbuhan sebesar $22,89 \%$ pertahunnya. Sedangkan pendapatan yang berasal dari komponen retribusi daerah, pada kurun waktu yang sama, memberikan kontribusi rata-rata per tahunnya sebesar $15,61 \%$ dengan rata-rata pertumbuhan pertahunnya sebesar $5,08 \%$ per tahun.

\section{Kerangka Konseptual}

Gambar 2.1. Kerangka Pikir Penelitian

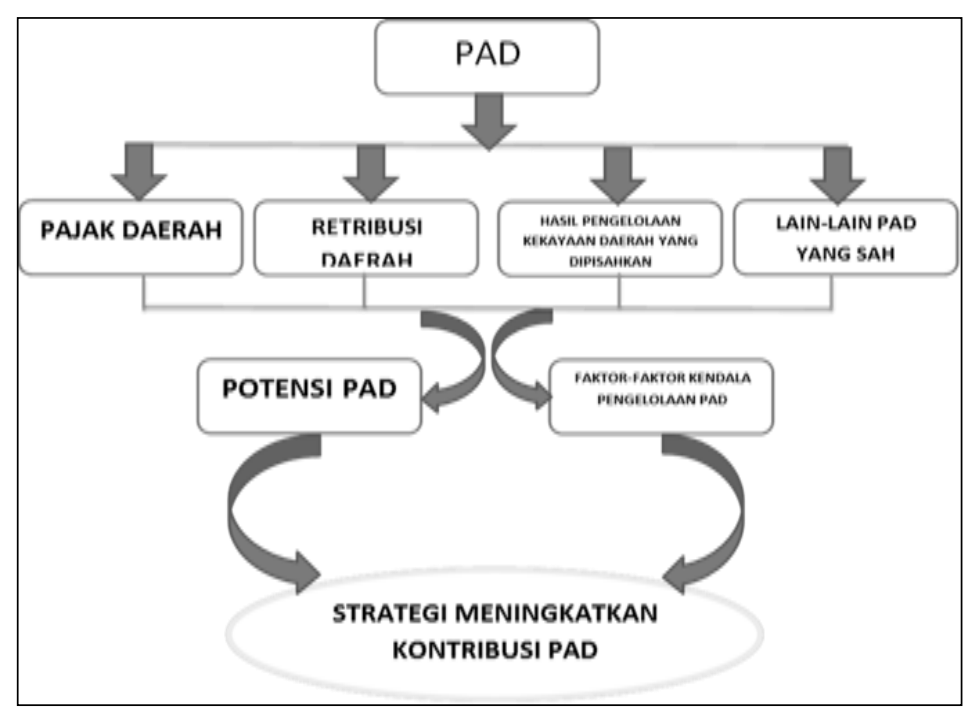

Sumber: Kerangka Pikir Penulis, 2015

\section{METODE PENELITIAN}

\section{Ruang Lingkup Penelitian}

Ruang lingkup penelitian ini adalah Peningkatan Pendapatan Asli Daerah (PAD) melalui Optimalisasi Pajak Daerah dan Retribusi Daerah di Kabupaten Jayapura sebagai bagian dari hasil upaya untuk mendorong peningkatan efisiensi dan efektivitas pemungutan dan pengelolaan PAD serta optimalisasi capaian realisasi selama ini. Oleh karena itu, ruang lingkup kegiatannya meliputi:

a) Pengumpulan data sekunder pada instansi terkait serta dari hasil-hasil kajian sebelumnya yang relevan.

b) Pengumpulan data primer dengan menggunakan instrumen kuesioner dan interview langsung dengan para responden. 
c) Identifikasi dan analisis mengenai kondisi existing atau potret kondisi aktivitas pemungutan dan pengelolaan PAD di Kabupaten Jayapura saat ini, baik secara ekstensifikasi maupun intensifikasi;

d) Analisis perbandingan antara hasil capaian realisasi PAD dengan potensi PAD yang tersedia;

e) Kajian dan analisis terhadap kemampuan menggali PAD sesuai potensi yang ada pada setiap sumber PAD;

f) Identifikasi dan analisis mengenai ketersediaan dan daya dukung sumberdaya, utamanya SDM, serta infrastruktur terhadap aktivitas pemungutan dan pengelolaan PAD di Kabupaten Jayapura saat ini;

g) Pelaksanaan presentasi dan diskusi (FGD) dalam rangka sosialisasi dan pembahasan hasil pekerjaan kepada Stakeholder di Kabupaten Jayapura guna memperoleh masukan bagi penyempurnaan laporan akhir hasil kegiatan.

h) Identifikasi dan analisis terhadap kendala atau permasalahan yang dihadapi dalam pelaksanaan aktivitas pemungutan dan pengelolaan PAD di Kabupaten Jayapura.

i) Pemetaan potensi PAD Kabupaten Jayapura berdasarkan klasifikasi dan jenis penerimaan.

\section{Teknik Pengumpulan Data, Jenis dan Sumber Data serta Metode Penarikan Sampel}

Teknik pengumpulan data yang digunakan adalah; wawancara, kuesioner, dan studi literatur. Jenis data yang diperlukan dalam penelitian ini adalah data primer dan data sekunder. Data primer dikumpulkan secara langsung dari para responden melalui wawancara, baik dengan menggunakan kuesioner maupun dengan cara wawancara langsung tanpa kuesioner (interview). Selain itu, jenis data primer dapat pula diperoleh dari hasil observasi atau pengamatan langsung terhadap aktivitas usaha yang dikelola oleh wajib pajak dan retribusi serta aktivitas pemungutan PAD yang dilaksanakan oleh para aparat pemungut pajak daerah dan retribusi daerah di lapangan.

Selanjutnya, data sekunder diperoleh dari instansi terkait, seperti Bappeda, Kantor Statistik, Dinas Pendapatan Daerah, Badan Pengelola Keuangan dan Aset Daerah, Dinas Perhubungan, serta SKPD-SKPD lainnya yang menjadi pemungut dan pengelola PAD di Kabupaten Jayapura. 
Populasi merupakan seluruh pelaku ekonomi yang terlibat dalam pelaksanaan aktivitas usaha pada setiap sektor ekonomi di Kabupaten Jayapura. Oleh karena karakteristik anggota populasi relatif heterogen, maka pengambilan sampel akan dilaksanakan melalui beberapa tahap dan menerapkan 2 metode yaitu Metode Cluster Sampling dan Metode Simple Random Sampling.

\section{Teknik Analisis Data}

Setelah data dan informasi yang diperoleh dari para informan diolah, maka selanjutnya perlu dianalisis untuk dapat mengetahui dan menganalisis peningkatan pendapatan asli daerah di Kabupaten Jayapura dalam era otonomi daerah ini. Untuk menganalisis data-data dan informasi yang diperoleh dalam peneltian ini, maka digunakan metode analisis statistik deskriptif dengan menggunakan skala Likert.

\section{Model Analisis}

Potensi suatu penerimaan pajak dapat dihitung dengan mengalikan tarif suatu pajak dengan basis pajak (dasar pengenaan pajak) sebagaimana ditentukan dalam undang-undang atau peraturan daerah yang menjadi dasar hukum pungutan tersebut (Hasan, 2003).

Potensi Penerimaan $=$ Tarif $\mathbf{x}$ Basis

Secara umum, dalam perencanaan penerimaan pajak daerah dan retribusi daerah terdapat 2 (dua) pendekatan, yaitu: pendekatan makro dan pendekatan mikro. Kedua pendekatan ini dapat diuraikan sebagai berikut:

\section{Pendekatan Makro.}

Hasan (2003) berpendapat bahwa teknik ini digunakan untuk mengestimasi sumber sumber penerimaan yang kecil yang tidak berdampak banyak terhadap seluruh penerimaan. Secara matematis, persamaan garis trend dapat ditulis sebagai berikut:

$$
\mathbf{Y}=\mathbf{a}+\mathbf{b X}
$$

Dimana:

$Y=$ Nilai Trend

$\mathrm{X}=$ Periode waktu

$\mathrm{a}=$ Konstanta, prediksi besaran $\mathrm{Y}$ pada periode dasar 
$\mathrm{b}=$ Koefisien trend, yang menunjukkan perkembangan/penurunan

\section{Pendekatan Mikro}

Pendekatan mikro dilakukan dengan menghitung masing-masing potensi dengan cara menyusun suatu formula atau rumus masing-masing jenis pajak dan retribusi. Sehingga formula untuk satu jenis pajak atau retribusi akan berbeda dengan formula jenis pajak atau retribusi lainnya. Potensi potensi pajak daerah atau retribusi daerah ditentukan oleh:

a. Jenis Pajak/Retribusi. Jenis pajak dan retribusi daerah diatur dalam UndangUndang No.28 Tahun 2009 yang dijabarkan dalam Peraturan Daerah Kabupaten atau Peraturan Bupati.

b. Tarif pajak/retribusi. Besarnya tarif diatur dalam Peraturan Daerah atau Peraturan Bupati Kabupaten Jayapura yang mengacu pada UU No.28 Tahun 2009.

c. Data Obyek Pajak. Salah faktor yang menentukan besar kecil penerimaan pajak daerah adalah jumlah objek pajak.

Sebagai contoh metode perhitungan dengan menggunakan metode mikro adalah metode perhitungan Pajak Hotel dan Restoran (Jamil dan Rahayu, 1997 dan Mardiasmo dan Ahmad, 2000) sebagai berikut:

a. Pajak Hotel

$$
\begin{aligned}
& Y_{j}=\sum_{i=1}^{n}\{\alpha i \times \beta i \times \delta i\} \times \theta \times 365 \text { hari } \\
& \mathrm{X}=\sum_{j=1}^{m} Y_{j}
\end{aligned}
$$

Dimana :

$Y_{j}=$ Potensi pajak hotel $\mathrm{j}$ selama satu tahun

$\alpha_{i}=$ Tarif kamar untuk jenis kamar i

$\beta_{i}=$ Jumlah kamar unuk jenis kamar $\mathrm{i}$

$\delta_{i}=$ Tingkat hunian (occupancy rate) untuk jenis kamar i

$\theta=$ Tarif pajak sesuai Perda No.7 Tahun 2012 yaitu 10 persen

$X=$ Total potensi pajak hotel selama satu tahun

\section{b. Pajak Restoran/Rumah Makaan}

Untuk mengetahui potensi pajak restoran maka digunakan rumus Potensi Pajak Restoran, sebagai berikut.

$V_{k}=\gamma \times \eta \times \lambda \times 365$ 
$Z=\sum_{k=1}^{l} V_{k}$

Dimana :

$V_{k}=$ Potensi pajak restoran $\mathrm{k}$ selama setahun

$\gamma=$ Rata-rata jumlah pengunjung

$\eta=$ Rata-rata harga menu

$\lambda=$ Tarif pajak restoran sesuai Perda No.7 Tahun 2012 yaitu 10 persen

$Z$ = Total potensi pajak restoran selama setahun

Kemudian untuk menentukan peta potensi penerimaan jenis pajak dan retribusi dilakukan pendekatan dengan menggunakan matriks (Jamil dan Rahayu, 1997 dan Mardiasmo dan Ahmad, 2000) seperti berikut:

\begin{tabular}{|c|c|c|}
\hline \multirow{2}{*}{ Rasio Pertumbuhan } & \multicolumn{2}{|c|}{ Rasio Proporsi } \\
\cline { 2 - 3 } & $\mathbf{X i} \mathbf{X} \geq \mathbf{1}$ (Tinggi) & $\mathbf{X i / X} \leq \mathbf{1}$ (Rendah) \\
\hline $\mathbf{d X i / d X} \geq \mathbf{1}$ (Tinggi) & $\begin{array}{c}\text { Sumber Unggulan } \\
\text { (Prima) }\end{array}$ & $\begin{array}{c}\text { Sumber } \\
\text { Berkembang }\end{array}$ \\
\hline $\mathbf{d X i / d X} \leq 1$ (rendah) & Sumber Potensial & Sumber Terbelakang \\
\hline
\end{tabular}

Keterangan:

a. Rasio Proporsi

Penentuan Rasio Proporsi dilakukan dengan membandingkan antara realisasi penerimaan pajak/retribusi dengan rata-rata penerimaan pajak/retribusi daerah. Rata-rata pajak/retribusi daerah diperoleh dari perhitungan seluruh penerimaan pajak/retribusi daerah dibagi dengan jumlaj jenis pajak/retribusi daerah.

b. Rasio Pertumbuhan

Penentuan rasio pertumbuhan dilakukan dengan membandingkan pertumbuhan jenis pajak/retribusi tertentu dengan pertumbuhan total pajak/retribusi daerah.

Berdasarkan analisis tersebut dirumuskan kebijakan yang dapat digunakan dalam rangka peningkatan potensi penerimaan PAD yang bersumber dari Pajak Daerah dan Retribusi Daerah.

Penilaian kinerja melalui perspektif kepuasan wajib pajak/retribusi daerah dengan variabel bukti langsung, keandalan, daya tanggap empati akan dinilai dari pernyataan positif (+) dan negatif (-). Menurut Niven (dikutip dari Wardika, 2004) pengukuran kinerja masing-masing variabel dapat dilakukan dengan dasar adanya pernyataan positif (ya) dan negatif (tidak).

Dalam penelitian ini jawaban yang terdiri dari empat kategori yakni : a) sangat setuju, b) setuju, c) tidak setuju, dan d) sangat tidak setuju akan digolongkan 
menjadi dua pernyataan dari empat kategori tersebut. Untuk kategori pernyataan positif (ya) meliputi jawaban dengan sangat setuju dan setuju, sedangkan untuk pernyataan negatif (tidak) meliputi jawaban tidak setuju dan sangat tidak setuju.

Selanjutnya untuk mengetahui kinerja aspek non finasial dilakukan perhitungan efektivitas kinerja (Devas, dkk; 1989 dan Mahmudi, 2009) dengan rumus:

\begin{tabular}{|c|c|}
\hline \multirow{2}{*}{ Efektivitas = } & Realisasi \\
\hline & Tarqet \\
\hline
\end{tabular}

Dimana :

Realisasi = Pedagang atau sampel yang menjawab pernyataan positif

Target = Jumlah total pedagang atau sampel

Pengukuran tingkat efektivitas non-keuangan menggunakan standar sesuai dengan acuan Litbang Depdagri Republik Indonesia tahun 1991 sebagai berikut:

a. Rasio efektif dibawah 40 persen = sangat tidak efektif

b. Rasio efektivitas antara $40-59,99$ persen $=$ tidak efektif

c. Rasio efektivitas antara 60-79,99 persen = cukup efektif

d. Rasio efektivitas diatas 80 persen $=$ sangat efektif

\section{Defenisi Operasional}

Berdasarkan penjelasan yang telah diuraikan sebelumnya, maka perlu dijabarkan variabel-variabel yang digunakan dalam kegiatan penelitian ini agar dapat tercipta pemahaman yang baik. Oleh karena itu, pada bagian ini diuraikan mengenai definisi operasional variabel-variabel tersebut sebagai berikut:

1. Pendapatan Daerah adalah hak pemerintah Kabupaten Jayapura yang diakui sebagai penambah nilai kekayaan bersih daerah ini dalam periode yang bersangkutan.

2. Pendapatan Asli Daerah (PAD) adalah pendapatan yang diperoleh pemerintah Kabupaten Jayapura yang dipungut berdasarkan peraturan daerah sesuai dengan peraturan perundang-undangan yang bersumber dari: (a) pajak daerah; (b) retribusi daerah; (c) hasil pengelolaan kekayaan daerah yang dipisahkan; dan (d) lain-lain PAD yang sah. 
3. Pajak Daerah adalah kontribusi wajib masyarakat kepada daerah yang terutang oleh orang pribadi atau badan yang bersifat memaksa berdasarkan Undang-Undang dengan tidak mendapatkan imbalan secara langsung dan digunakan untuk keperluan daerah bagi sebesar-besarnya kemakmuran rakyat.

4. Retribusi Daerah adalah pendapatan yang diperoleh pemerintah Kabupaten Jayapura atas pelayanan yang disediakan atau diberikan untuk pemenuhan kepentingan dan kemanfaatan masyarakat serta dapat dinikmati oleh orang pribadi atau badan.

5. Hasil pengelolaan kekayaan daerah yang dipisahkan adalah pendapatan daerah yang diperoleh pemerintah Kabupaten Jayapura dari sumber objek pendapatan yang mencakup bagian laba atas penyertaan modal pada perusahaan milik daerah/BUMD, bagian laba atas penyertaan modal pada perusahaan milik negara/BUMN dan bagian laba atas penyertaan modal pada perusahaan milik swasta atau kelompok masyarakat.

6. Lain-lain pendapatan asli daerah yang sah adalah Pendapatan asli Daerah yang sah disediakan untuk menganggarkan penerimaan daerah yang tidak termasuk dalam jenis pajak daerah, dan hasil pengelolaan kekayaan daerah yang dipisahkan. jenis pendapatan ini meliputi objek pendapatan dari: (a) Hasil penjualan kekayaan daerah yang tidak dipisahkan; (b) Penerimaan Jasa Giro; (c) Pendapatan Bunga; (d) Denda keterlambatan pelaksanaan pekerjaan; dan (e) Penerimaan ganti rugi atas kerugian/kehilangan kekayaan daerah.

7. Potensi PAD adalah kapasitas potensial sumber-sumber PAD yang tersedia di Kabupaten Jayapura yang dapat digali oleh pemerintah Kabupaten Jayapura untuk mengoptimalkan penerimaan PAD daerah ini.

\section{HASIL DAN PEMBAHASAN}

\section{Potensi Pendapatan Asli Daerah Kabupaten Jayapura.}

Dalam kerangka pembangunan daerah yang dijiwai oleh Otonomi Daerah, Pendapatan Asli Daerah merupakan pilihan utama bagi setiap daerah sebagai sumber pembiayaan pengeluaran pembangunan. Pemerintah daerah selalu memanfaatkan potensi yang dimilikinya guna menunjang kontribusi PAD terhadap total pendapatan daerah. Dalam pengelolaan PAD ada beberapa komponen yang mendukung namun dalam pembahasan ini lebih menekankan pada potensi pajak 
dan retribusi daerah sebagai sektor yang lebih dominan potensinya. Pajak dan retribusi daerah mempunyai hubungan yang kuat dimana kedua sumber ini menjadi penyumbang utama bagi komponen PAD namun keduanya juga memiliki perbedaan dimana pajak merupakan kewajiban yang harus dibayarkan tanpa diminta walaupun pemerintah tidak menyediakan infrastrukturnya. Sedangkan retribusi akan dilaksanakan penarikan apabila pemerintah menyediahkan infrastruktur pendukungnya. Kontribusi Pendapatan Asli Daerah terhadap total pendapatan daerah dari masing - masing sumber berbeda, tergantung kondisi daerah tersebut. Kontribusi PAD dari pajak daerah lebih besar sumbangannya bila dibandingkan dengan kontribusi dari sektor retribusi. Kondisi ini dibarengi dengan pertumbuhan ekonomi yang didukung oleh pihak swasta cukup dominan, sedangkan retribusi belum terlalu besar kontribusinya terhadap PAD karena pemerintah belum maksimal menyediahkan infrastruktur pendukung pengelolaan retribusi daerah. Oleh karena itu diperlukan pengkajian yang mendalam untuk menentukan langkahlangkah kebijaksanaan yang tepat dalam upaya mendorong peningkatan kontribusi Pendapatan Asli Daerah pada kedua sektor tersebut, dimasa yang akan datang dengan memanfaatkan potensi pajak dan retribusi , sehingga pada saatnya nanti dapat menjadi andalan pembiayaan dalam pelaksanaan pembangunan.

Berdasarkan pada gambaran komposisi sumber pendapatan asli daerah yang telah dijelaskan pada sub bab sebelumnya, maka pada bagian ini akan dianalisis potensi pendapatan dari masing-masing pembentuk PAD di Kabupaten Jayapura berdasarkan sumber penerimaan khusus pada pajak daerah dan retribusi daerah.

\section{Potensi Pajak Daerah Kabupaten Jayapura.}

Pajak Daerah merupakan salah satu sumber penerimaan yang potensial bagi Kabupaten Jayapura. Berdasarkan perkembangan target dan realisasi penerimaan PAD Kabupaten Jayapura selama lima tahun terakhir mengalami peningkatan dari tahun ke tahun selama periode 2010-2014.

Tabel 4.1

Target dan Realisasi Pajak Daerah Kabupaten Jayapura

Tahun 2010-2014

\begin{tabular}{|c|c|c|c|}
\hline Tahun & Target & Realisasi & $\%$ \\
\hline 2010 & $3,020,000,000$ & $4,701,707,092$ & 155.69 \\
\hline 2011 & $4,755,982,898$ & $5,493,359,441$ & 115.50 \\
\hline
\end{tabular}




\begin{tabular}{|c|c|c|c|}
\hline 2012 & $5,516,630,000$ & $8,593,187,623$ & 155.77 \\
\hline 2013 & $8,321,200,000$ & $11,371,630,738$ & 136.66 \\
\hline 2014 & $23,694,153,907$ & $28,247,804,695$ & 119.22 \\
\hline \multicolumn{3}{|r|}{ Rata-Rata Realisasi } & $\mathbf{1 3 6 . 5 7}$ \\
\hline
\end{tabular}

Sumber: Dinas Pendapatan Daerah (Data diolah), Tahun 2015

Pada Tabel 4.1 di atas nampak bahwa realisasi pendapatan asli daerah Kabupaten Jayapura yang bersumber dari Pajak Daerah selalu melebihi target yang ditetapkan dengan rata-rata realisasi 136,57 persen dari tahun 2010-2014. Pada tahun 2010 dan 2012 besarnya realisasi pendapatan asli daerah yang bersumber dari pajak daerah berada diatas 150 persen dari target yang telah ditetapkan. Capaian realisasi tersebut jika dilihat dari perbandingan antara target dan realisasi maka secara sederhana dapat disimpulkan bahwa peran pelakasana pengelolah PAD khususnya yang mengelolah penerimaan pajak daerah menunjukkan kinerja yang cukup tinggi. Akan tetapi jika dianalisis secara mendalam, maka realisasi yang selalu melampauhi target tersebut bisa jadi sebabkan karena penentuan target terlalu rendah sehingga dengan mudah dapat dicapai atau dilampauhi. Sebagai bukti nyata selama lima tahun terakhir realisasi penerimaan melampuhi target yang ditetap. Hal tersebut mengindisikan bahwa target yang ditetapkan tidak berdasarkan pada potensi yang dimiliki oleh daerah.

Untuk itu pada periode mendatang penentuan target penerimaan hendaknya memperhatikan terlebih dahulu potensi yang dimiliki oleh daerah.

\section{Potensi Retribusi Daerah}

Retribusi daerah adalah suatu pembayaran dari rakyat kepada pemerintah daerah dalam bentuk balas jasa yang langsung diterima dengan adanya pembayaran retribusi tersebut. Retribusi Daerah Kabupaten Jayapura diatur dalam tiga perda yakni Perda No. 8 Tahun 2012 tentang retribusi jasa umum, Perda No.9 Tahun 2012 tentang retribusi jasa usaha dan Perda No. 10 Tahun 2012 tentang perizinan tertentu. Ketiga perda tersebut adalah penjabaran dari UU No.28 Tahun 2009. Dengan demikian retribusi merupakan potensi ekonomi yang cukup berarti dalam penerimaan daerah. Sebagai salah satu sumber penerimaan daerah,maka penggalian dan pemanfaatan potensi retribusi daerah perlu senantiasa dimaksimalkan pengelolaannya.

Berdasarkan data publikasi Dinas Pendapatan Daerah Kabupaten Jayapura, nampak bahwa selama periode tahun 2010-2014, realisasi penerimaan retribusi daerah mengalami kenaikan dari tahun ke tahun kecuali pada tahun 2012 mengalami penurunan dari tahun sebelumnya. Sementara realisasi tertinggi terjadi 
pada tahun 2014 yakni sebesar Rp. 20.556.692.293 atau hampir tiga kali lipat pada tahun 2010 (lihat Tabel 4.2). Untuk menganalisis potensi retribusi daerah di Kabupaten Jayapura di bagi atas tiga bagian berdasarkan jenis retribusi.

Tabel 4.18

Target dan Realisasi Retribusi Daerah Kabupaten Jayapura Tahun 2010-2014

\begin{tabular}{|c|c|c|c|}
\hline Tahun & Target & Realisasi & $\%$ \\
\hline 2010 & $7,407,505,638$ & $8,549,482,206$ & 115.42 \\
\hline 2011 & $8,449,693,300$ & $7,992,062,457$ & 94.58 \\
\hline 2012 & $6,452,491,921$ & $5,759,178,355$ & 89.26 \\
\hline 2013 & $7,050,771,815$ & $8,466,385,867$ & 120.08 \\
\hline 2014 & $18,128,288,591$ & $20,556,692,293$ & 113.40 \\
\hline
\end{tabular}

Sumber: Dinas Pendapatan Daerah (data diolah), Tahun 2015

\section{Faktor-faktor Kendala}

Pemkab Jayapura dalam mengidentifikasi dan menggali serta memanfaatkan potensi-potensi PAD melalui efisiensi dan efektifitas pengelolaan pajak dan retribusi daerah, memiliki keterkaitan yang kuat terhadap peningkatan kinerja pemerintah itu sendiri. Hal ini dapat dilakukan dengan cara peningkatan mobilisasi kinerja pelayanan pada instansi-intansi pemerintah yang mempunyai konektifitas kuat terhadap pemberdayaan potensi-potensi PAD. Kendala-kendala dalam meningkatkan pelayanan tersebut dapat berupa:

a) Penetapan target capaian pengelolaan pajak dan retribusi yang tidak menggunakan analisa yang akurat;

b) Masih rendahnya kepekaan pemerintah dalam mengidentifikasi potensi-potensi sumber peningkatan PAD;

c) Masih rendahnya sumberdaya manusia atau kompetensi pengelola pajak dan retribusi daerah;

Selain penentuan target capaian dan peningkatan kepekaan dalam mengidentifikasi potensi sumber pendapatan, penelitian ini juga membahas tentang pentingnya peningkatan pendapatan melalui pengembangan SDM pengelola pajak dan retribusi. Baiknya pelayanan yang ditunjukan oleh pengelola perpajakan dan retribusi dapat pula menjadi salah satu sumber penciptaan citra yang baik dikalangan wajib pajak sehingga dapat meningkatkan kepercayaan publik terhadap 
kinerja pemerintah dalam upaya peningkatan pendapatan daerah. Secara spesifik ada beberapa dilema terkait kemampuan pengelolaan potensi pajak dan retribusi daerah, seperti:

1. Sekalipun terdapat potensi pajak dan retribusi daerah yang tinggi, masih terdapat kemampuan pengelolaan yang rendah atau dengan kata lain proses intensifikasi belum diimplementasikan secara baik;

2. Kurangnya promosi dan ekspansi bilamana terdapat potensi tinggi dan kemampuan mengelola yang tinggi akan potensi pajak dan retribusi daerah yang berhasil diidentifikasi;

3. Jika terdapat kemampuan pengelolaan potensi yang memadai, kuantitas potensi akan pajak yang ada berbanding terbalik dengan kemampuan pengelolaan yang tinggi, dan hal ini tidak didukung pula dengan adanya proses ekstensifikasi yang efektif;

4. Rendahnya potensi pajak yang teridentifikasi, ditopang juga dengan kemampuan mengelola yang rendah. Hal ini dapat terjadi karena belum dilaksanakannya edukasi dan pengembangan kapasitas serta kapabilitas pengelola pajak dan retribusi daerah secara berkesinambungan

\section{Strategi Peningkatan Sumber Pendapatan Asli Daerah}

Keberhasilan pengelolaan penerimaan daerah tidak hanya semata diukur dari jumlah penerimaan yang dapat dicapai, tetapi sejauh mana pajak daerah dan retribusi daerah serta sumber penerimaan lainnya dapat berperan mengatur perekonomian masyarakat agar dapat bertumbuh kembang.yang pada gilirannya dapat meningkatkan kesejahteraan masyarakat di daerah. Secara teoritis kemampuan keuangan daerah dapat ditingkatkan dengan intensifikasi dan atau ekstensifikasi. Upaya ekstensifikasi adalah upaya perluasan jenis pungutan. Upaya intensifikasi adalah upaya meningkatkan kemandirian penerimaan daerah dengan meningkatkan kinerja pajak dan retribusi daerah yang ada. Upaya ini menuntut kemampuan daerah untuk dapat mengidentifikasi secara sahib potensi penerimaan daerah dan kemudian mampu memungutnya dengan berdasar pada asas manfaat dan asas keadilan.Lebih lanjut, untuk mencapai hal tersebut berbagai sumber daya (software dan hardware) yang digunakan untuk memungut dan strategi pemungutan perlu segera disiapkan.

Dalam jangka pendek kegiatan yang paling mudah dan dapat segera dilakukan adalah melakukan intensifikasi terhadap obyek atau sumber pendapatan daerah yang sudah ada melalui penghitungan potensi dengan penyusunan sistem 
informasi basis data potensi. Dengan melakukan efektifitas dan efisiensi sumber atau obyek pendapatan daerah, maka akan meningkatkan produktivitas penerimaan daerah tanpa harus melakukan perluasan sumber atau obyek pendapatan bare yang memerlukan studi, proses dan waktu yang panjang. Estimasi potensi melalui penyusunan basis data yang dibentuk dan disusun dari variabelvariabel yang merefleksikan masing-masing jenis penerimaan. (pajak, retribusi dan penerimaan lain-lain) sehingga dapat menggambarkan kondisi potensi dari suatu jenis penerimaan.

Secara umum, upaya yang perlu dilakukan oleh Pemerintah Daerah dalam rangka meningkatkan pendapatan daerah melalui optimalisasi intensifikasi pemungutan pajak daerah dan retribusi daerah, antara lain dapat dilakukan dengan cara-cara sebagai berikut:

1. Memperluas basis penerimaan. Tindakan yang dilakukan untuk memperluas basis penerimaan yang dapat dipungut oleh daerah, yang dalam perhitungan ekonomi dianggap potensial, antara lain yaitu mengidentifikasi pembayar pajak baru/potensial dan jumlah pembayar pajak, memperbaiki basis data objek, memperbaiki penilaian, menghitung kapasitas penerimaan dari setiap jenis pungutan.

2. Memperkuat proses pemungutan. Upaya yang dilakukan dalam memperkuat proses pemungutan, yaitu antara lain mempercepat penyusunan Perda, mengubah tarif khususnya tarif retribusi.

3. Peningkatan kapasitas pengelola penerimaan daerah. Kapasitas pengelola penerimaan daerah merupakan salah satu kunci keberhasilan optimalisasi penerimaan daerah. Upaya yang dapat dilakukan antara lain melalui

a. Menyeimbangkan kebutuhan pengelola secara kualitatif dan kuantitatif,

b. Penerimaan tenaga pengelola.

c. Pelatihan tenaga pengelola

d. Pemenuhan aspek kesejahteraan tenaga pengelola (gaji, upah pungut, karir dan sistem pensiun).

4. Meningkatkan pengawasan. Hal ini dapat ditingkatkan yaitu antara lain dengan melakukan pemeriksaan secara dadakan dan berkala, memperbaiki proses pengawasan, menerapkan sanksi terhadap penunggak pajak dan sanksi terhadap pihak fiskus, serta meningkatkan pembayaran pajak dan pelayanan yang diberikan oleh daerah. Upaya yang dapat dilakukan antara lain:

a. Pengawasan terencana. 

b. Inspeksi mendadak.
c. Konsistensi penerapan sanksi.

5. Meningkatkan efisiensi administrasi dan menekan biaya pemungutan. Tindakan yang dilakukan oleh daerah yaitu antara lain memperbaiki prosedur administrasi pajak melalui penyederhanaan admnistrasi pajak, meningkatkan efisiensi pemungutan dari setiap jenis pemungutan..

6. Meningkatkan kapasitas penerimaan melalui perencanaan yang lebih baik. Hal ini dapat dilakukan dengan meningkatkan koordinasi dengan instansi terkait di daerah.

7. Meningkatkan kesadaran wajib pajak/retribusi. Perlu dilakukan penumbuhan kesadaran bahkan kebanggaan WP/WR membayar pajak/retribusi sebagai andil mereka membangun daerahnya. Kegiatan yang dapat dilakukan adalah
a. Melalui pendekatan persuasif-partisipatif,
b. Melakukan penyuluhan pajak dan retribusi,
c. Pelaksanaan pelayanan prima.

\section{KESIMPULAN}

Berdasarkan hasil analisis diatas dapat disimpulkan :

a. Kontribusi PAD yang masih relatif rendah disebabkan oleh kurangnya pemanfaatkan sumber-sumber potensi PAD, terutama pajak dan retribusi daerah. Padahal Kabupaten Jayapura memiliki potensi pajak daerah yang cukup besar tapi belum dikembangkan dan dioptimalkan pemungutannya selama ini.

b. Kabupaten Jayapura memiliki pula potensi retribusi daerah yang cukup besar tetapi belum dikembangkan dan dioptimalkan pemungutannya selama ini, sehingga belum mampu memberikan kontribusi kepada PAD secara signifikan selama ini. Jenis-jenis retribusi daerah ini yang cukup potensil tersebut adalah Retribusi pelayanan kesehatan, izin gangguan, dan retribusi pelayanan persampahan.

c. Ada beberapa faktor kendala yang dihadapi, sehingga kontirbusi pajak daerah dan retribusi daerah terhadap PAD belum optimal selama ini, yakni:

- Manajemen pengumpulan pajak yang kurang baik sebagai akibat dari masih rendahnya kepekaan pemerintah dalam mengidentifikasi potensi-potensi sumber peningkatan PAD, 
- Data tentang obyek pajak kurang akurat sebagai akibat dari masih rendahnya kompetensi SDM aparatur pengelola pajak dan retribusi daerah,

- Penetapan target tidak berdasarkan/tidak sesuai dengan kenyataan yang ada di lapangan (berdasarkan potensi) dan tidak menggunakan analisis yang akurat, tetapi hanya berdasarkan pada data historis dan perkiraan-perkiraan dari tahun sebelumnya,

- Adanya penghindaran pajak (tax aversion) oleh wajib pajak karena kurangnya kesadaran masyarakat untuk membayar pajak,

- Kurangnya kerjasama dengan pihak yang terkait dalam penentuan target dan perealisasian pajak,

- Daya tanggap dan empati petugas terhadap wajib pajak/retribusi belum maksimal yang dibutikan oleh tanggapan responden pada kategori sangat tidak efektif dan tidak efektif atau sebagian besar responden menilai negatif,

- Rendahnya potensi pajak yang teridentifikasi, ditopang juga dengan kemampuan mengelola yang rendah. Hal ini dapat terjadi karena belum dilaksanakannya edukasi dan pengembangan kapasitas serta kapabilitas pengelola pajak dan retribusi daerah secara berkesinambungan.

d. Beberapa bentuk strategi yang efektif diterapkan untuk meningkatkan kontribusi penerimaan dari Pajak Daerah dan Retribusi Daerah terhadap PAD di masa datang adalah:

- Penetapan target penerimaan pajak daerah dan retribusi daerah dilaksanakan menerapkan gabungan metode Incremential dan kemampuan merealisasikan target pada tahun sebelumnya yang ditopang dengan hasil analisis potensi yang akurat dan valid,

- Penguatan kerjasama dan pelibatan stakeholder dalam pengelolaan pajak daerah dan retribusi daerah,

- Peningkatan intensitas sosialisasi kepada wajib pajak dan retribusi mengenai pajak daerah dan retibusi daerah yang menjadi kewajiban mereka untuk membayarnya,

- Pengembangan penggalian potensi jenis-jenis pajak daerah dan retribusi daerah yang belum tergali secara optimal, sebagaimana yang telah ditetapkan dalam UU No. 28 tahun 2009 tentang Pajak 
daerah dan Retribusi Daerah,

- Peningkatan profesionalisme SDM aparatur pemungut dan pengelola pajak daerah dan retribusi daerah,

- Pengutan fungsi pengawasan terhadap wajib pajak dan retribusi daerah serta terhadap SDM aparatur pemungutnya.

\section{DAFTAR PUSTAKA}

Adriansyah, 2003. Perimbangan Keuangan Pusat dan Daerah dalam Kerangka Pelaksanaan Otda. UPP-YKPN, Yogyakarta

Amstrong, Michael (1994), Performance Management, England : Clays, St Ives Plc

Arikunto, Suharsimi (2002), Prosedur Penelitian, Suatu Pendekatan Praktek, Rireka Cipta, Jakarta

Bacal, Robert (2002), Performance Management , PT. Gramedia Pustaka Utama, Jakarta

Bernardin, Jhon H. And Russel (1993), Human Resource Management, MC GrawHill, Inc, Singapore

Brarata, A.A (2003), Dasar - dasar Pelayanan Prima, Gramedia, Jakarta

Bresser F.K, Rudi dan Klermens Millonog (2003), Institutional Capital: Competitive Advantage in light of the new instituitiolism in organizationa theory, scharmalenbach business review, Vol 55 July. PP.220-241

Cullen and D'innocenzo (2004) Memaksimalkan Kinerja Alih Bahasa Andi, Tugu Publisher, Yogyakarta

Deddy S, Bratakusumah dan D, Solihin, 2001. Otonomi Penyelenggaraan Pemerintahan Daerah. Gramedia Pustaka Utama, Jakarta.

Devas, Nick, dkk (1989) Keuangan Pemerintah Daerah di Indonesia (terjemahan oleh Masri Maris), UI-Press, Jakarta.

Dwiyanto, Agus, 2002, Reformasi Birokrasi Publik di Indonesia, Cetakan Pertama, Galang Printika, Yogyakarta

Elita Dewi, Identifikasi Sumber Pendapatan Asli Daerah dalam Rangka Pelaksanaan Otonomi Daerah, Fakultas Ilmu Sosial dan Ilmu Politik Universitas Sumatera Utara.

Halim, Abdul. 2004. Bunga Rampai Manajemen Keuangan Daerah. UPP-YKPN, Yogyakarta.

Hasan, Iqbal. 2003. Statistik Deskriptif. Cetakan kedua, Bumi Aksara, Jakarta .

Hoessein, Bhenyamin, 2002. Perspektif Jangka Panjang Desentralisasi dan Otda. Gramedia Pustaka, Jakarta.

Husaini, Martani (1997) Balanced Scorecard Penyeimbang Pengukuran Kinerja Organisasi, dalam Majalah Manajemen dan Usahawan Indonesia Nomor, 06/th XXVI Juni 1997 
Implementasi Balanced Scorecard ( No. 04 Tahun 2004), Majalah Human Capital

Implementasi Balanced Scorecard pada Bank Indonesia ( No. 16 Juli 2005) Majalah Human Capital

Insukindro, Mardiasmo., Wahyu Widayat, Wihana Kirana Jaya, Purwanto, Abdul Halim, John Suprihanto, Budi Purnomo. (1994). Peranan Pengelolaan Keuangan Daerah dalam usaha peningkatan PAD. Laporan hasil penelitian KKD. FE - UGM, Yogyakarta.

Jamil dan Rahayu, (1997). Analisis Pajak Pembangunan I Perhotelan sebagai Sumber Pendapatan Asli Daerah, JEP Vol.2 No.3, Hal 310-323.

Jhonson, Redmon Mawhinney (2004), Hand Book of Organizational Performance, Analisis Perilaku dan Manajemen Alih Bahasa Andi Tugu Publisher, Yogyakarta

Kaplan, R.S dan Norton D.P (1996) Konsep Manajemen Baru Mencapai Kinerja dengan Integritas, alih bahasa Edy Sukarno dan V, Djemadu PT. Gramedia Pustaka Utama, Jakarta

Kasim (1993), Pengukuran Efektifitas dalam Organisasi Universitas Indonesia, Jakarta

Keban, T. Yeremias (1995), Indikator Kinerja Pemerintah Daerah : Pendekatan Manajemen dan Kebijakan, Makalah Seminar Sehari Fisipol UGM Yogyakarta

Kotler, Philip (1995) Manajemen Pemasaran Analisis, Perencanaan Implementasi dan Pengendalian Edisi Indonesia Salemba Jakarta

Kumorotomo, Wahyudi (2003), Etika Administrasi Negara, Raha Grafindo Persada Jakarta

Kuncoro, Mudrajat,1995, Desentralisasi Fiskal di Indonesia, Dilema Otonomi dan Ketergantungan, Journal : Prisma, No.4, hal. 3-17.

Lovelock, C.H (1992), Managing Service Marketing, Operation and Human Resource, New Dehli, Pretince Hill

Lubis, H dan Husaini, M (1987), Teori Organisasi Pendekatan Makro, FE Universitas Indonesia, Jakarta

Ma'arif Syamsul, Tanjung Hendri (2003), Teknik - teknik kuantitatif untuk Manajemen, Grasindo Jakarta

Mahmudi (200(. Manajemen Keungan Daerah, Penerbit Erlangga, Jakarta.

Mahsun, Mohamad (2009), Pengukuran Kinerja Sektor Publik, BPFE, Yogyakarta

Mardiasmo. (2004). Otonomi dan Manajemen Keuangan Daerah. Penerbit Andi, Yogyakarta.

Mardiasmo dan Ahmad M (2000). Perhitungan Potensi Pajak dan Retribusi Daerah di Kabupaten Magelang, Laporan Akhir. Kerjasama Pemerintah Daerah Kabupaten Magelang dengan PAU-SE UGM, Yogyakarta.

Mirza, Teuku, (1994) Balanced Scorecard Dalam Majalah Manajemen dan Usahawan Indonesia Nomor 06/Th XXVI JUni 1994 
Mulyadi (2005), Sistem Manajemen Strategik Berbasis Balanced Scorecard, UPPAMP YKPN, Yogyakarta

Mulyadi (2007), Sistem Terpadu Pengelolaan Kinerja Personel Berbasis Balanced Scorecard, UPP-STIE YKPN, Yogyakarta

Noor Fuad (2004), Kebijakan Fiskal, Pemikiran, Konsep dan Implementasi Kompas, Jakarta

Nordiawan, Deddi (2006) Akuntasi Sektor Publik, Salemba Empat, Jakarta

Osbome (1999) Mewirausahakan Birokrasi, Alih Bahasa Abdul Rosyid, Pustaka Binaman Presindo, Jakarta

Pedoman Penulisan Usulan Penelitian (Proposal) \& Thesis Program Magister Manajemen Universitas Sam Ratulangi Manado.

Peraturan Pemerintah RI Nomor 8 Tahun 2006, Tentang Pelaporan Keuangan dan Instansi Pemerintah

Prasetya, Edy (2004) Penyusunan dan Analisa Laporan Keuangan Pemerintah Daerah, Andi Effset, Yogyakarta

Prianto, Agus (2006), Menakar Kualitas Pelayanan Publik, In-trans, Malang

Propovich, M.G (1998) Creating High Performance Government Organization, Allieance for Redesingning Government

Purwadarminto, Kamus Lengkap Inggris - Indonesia

Purwadinata, Subhan (2010) "Analisis Potensi Pendapatan Asli Daerah dan Strategi Peningkatan Kemampuan Keuangan Daerah”, Studi di Kabupaten Sumbawa, Indonesia.

Rampersad, Hubert K. (2005), Total Performance Scorecard, Konsep Manajemen Baru Mencapai Kinerja dengan integritas, Alih Bahasa Edy Sukarno dan Djemanu, Gramedia Pustaka Utama, Jakarta

Ratminto, Atik Septi Winarsih, 2005, Manajemen Pelayanan Cetakan I, Pustaka pelajar, Yogyakarta

Razak, Rahman, Abd. 2009. Esensi Pembangunan Ekonomi Daerah. Nala Cipta Litera, Makassar.

Republik Indonesia. (2004). Undang-undang Nomor 32 Tahun 2004 tentang Pemerintahan Daerah. Sinar Grafika, Jakarta.

Republik Indonesia. (2004). Undang-undang Nomor 33 Tahun 2004 tentang Perimbangan Keuangan antara Pemerintah Pusat dan Daerah. Sinar Grafika, Jakarta.

Riduansyah, Muhammad (2003), 'Kontribusi Pajak Daerah dan Retribusi Daerah Terhadap Pendapatan Asli Daerah (PAD) dan Anggaran Pendapatan dan Belanja Daerah (APBD'), Indosnesia, Jakarta.

Robin, Stephen P (2006) Perilaku Organisasi Indeks Jakarta

Ruky, Achmad (2004), Sistem Manajemen Kinerja, Gramedia Jakarta

Salomo, Roy (2003) Anggaran yang Berorientasi pada kinerja dan Kepemerintahan yang baik, Majalah Inovasi Vol. 5 Desember - Februari 2003 
Salusu, J, 2003, Pengambilan Keputusan Strategik untuk Organisasi Publik Nonprofit, Pt, Grasindo, Jakarta

Sandra S. Lang (1999), Balanced Scorecard dan Government Entities, Moving Forward at the lilinois Departement of Transportation.

Saragih, Juli Panglima. (2003). Desentralisasi Fiskal dan Keuangan Daerah Dalam Otonomi. Ghalia Indonesia, Jakarta

Saunders (2006), Strategi Penilaian Kinerja Karyawan, Alih Bahasa At's Line Tugu Publisher Yogyakarta

Siagian Sondang (1985), Analisis Perumusan Kebijakasanaan dan Starategi Organisasi, Gunung Agung, Jakarta

Sidik, Machfud, 2003. "Format Hubungan Keuangan Pemerintah Pusat dan Daerah Yang Mengacu Pada Pencapaian Tujuan Nasional". Bunga Rampai Desentralisasi Fiskal. Departemen Keuangan, Jakarta.

Simanjuntak Payaman (2005), Manajemen dan Evaluasi Kinerja, FE Universitas Indonesia, Jakarta

Subagyo (2004), Metode Penelitian, Asdi Mahasatya, Jakarta

Sugiyono (1997), Statistika untuk penelitian, CV. Alfa Beta Bandung

Sugiyono (1999), Metode Penelitian Bisnis, CV. Alfa Beta Bandung

Sugiyono (2003), Metode Penelitian Admnistrasi, CV. Alfa Beta Bandung

Sukses Dengan Balanced Scorecard (Juli 2005), Majalah Human Capital

Sulistiyani dan Rosidah (2003), Konsep Teori dan Pengembangan dalam Konteks Organisasi Publik, Graha Ilmu Yogyakarta

Suwandi Made (2003), Penilaian Kinerja Pelayanan Publik

Thoha Miftah (2005), Manajemen Kepegawaian Sipil di Indonesia, Prenada Media Jakarta

Tika Pembudu (2006), Budaya Organisasi dan Peningkatan Kinerja Perusahaan, Bumi Aksara, Jakarta

Tjandra Riawan (2006), Hukum Keuangan Negara Grasindo, Jakarta

Umar Hussein (1999), Riset Sumber Daya Manusia dalam Organisasi, Gramedia Pustaka Utama, Jakarta

Undang-Undang Nomor 28 Tahun 2009 tentang Pajak Daerah dan Retribusi Daerah (Lembaran Negara Republik Indonesia Tahun 2009 Nomor 130, Tambahan Lembaran Negara Republik Indonesia Nomor 5049).

Undang-Undang Republik Indonesia Nomor 33 Tahun 2004 Tentang Perimbangan Keuangan Antara Pemerintah Pusat dan Pemerintah Daerah.

Vincent Gasperz (2006), Sistem Manajemen Kinerja Terintegrasi Balanced Scorecard dengan Six Sigma untuk OrganisasiBisnis dan Pemerintah, PT. Gramedia Pustaka Utama, Jakarta 
Wardono, Aditya, et. al (2012), Kajian Pemetaan dan Optimalisasi Potensi Pajak Dalam Rangka Meningkatkan Pendapatan Asli Daerah di Kabupaten Jember, Indonesia.

Winarno, Budi (2004), Teori dan ProsesKebijakan Publik, Media Pressindo, Yogyakarta

Yani, Ahmad, 2008, Hubungan Keuangan antara Pemerintah Pusat dan Daerah di Indonesia. PT RajaGrafindo Persada, Jakarta

Yuwono, Seny, Jukarno, Ikhsan (2003), Petunjuk Praktis Penyusunan Balanced Scorecard, menuju organisasi yang berfokus pada strategi, Gramedia Pustaka Utama, Jakarta. 